\title{
HISTORICAL STUDY OF JINJA, UGANDA: A CITY INFLUENCED BY INDUSTRIAL DEVELOPMENTS DURING THE EARLY 20TH CENTURY
}

\author{
ANTHONY K. WAKO \& MARK R. O. OLWENY \\ Faculty of the Built Environment, Uganda Martyrs University, Uganda
}

\begin{abstract}
This paper evaluates how industrial developments during the first three decades of the 20th century contributed to the founding and growth of Jinja. During this period Jinja grew to become an important inland port on Lake Victoria, a consequence of geography, as well as a multitude of conditions and circumstances linked to colonial developmental policies. The paper presents the socio-economic and socio-political context of colonial patronage which influenced the spatial developments of Jinja. It, however, makes a case that some industrial aspects were in place before Jinja was designated as the pre-eminent industrial hub of Uganda. The paper frames historical narratives through developmental paradigms. By selecting different lenses to cross-examine the growth of Jinja, the paper highlights themes of trade, transport and planning that influenced and shaped the growth of the city. Research for this paper draws primarily on historical information, through critical analysis with reference to embryonic urban centres in other British controlled territories across sub-Saharan Africa, as a means to better situate the conditions that shaped Jinja. The study of Jinja's history also forms a basis for conservation policies and could be an instrument for promoting ideas of development which are compatible with Jinja's genius loci.
\end{abstract}

Keywords: trade, transport, planning, colonial developments, industrial developments, colonial patronage.

\section{INTRODUCTION}

A scarcity of raw materials for industries in Britain at the start of the 20th century forced it to seek materials from its colonies. As a consequence, in British controlled territories across sub-Saharan Africa, urban centres whose primary functions related to extractive industries emerged, and included: Jinja in the Uganda Protectorate, Lusaka in Northern Rhodesia (Zambia), Nairobi and Port Florence (Kisumu) in British East Africa (Kenya), Port Harcourt in Nigeria, Salisbury (Harare) in Southern Rhodesia (Zimbabwe), These centres became export-import relay points (transport centres with railway administration at the helm) within the context of the colonial economy [1]. Industrial development in these urban centres across colonial Africa was described by King and Van Zwanenburg [2] as a process of industrialisation that originated out of the growth of Western industrialisation rather than out of the process of indigenous savings and knowledge, predicated on the extraction of raw materials with the associated infrastructure built to support this activity. As a consequence, these urban centres of European creation developed with multiple layers based on ethnicity among different issues [3]. The contribution of industrial developments to these centres is an important area for exploration as part of a need to appreciate the origins and growth of these towns as more than mere historic footnotes in the colonial project. This paper unpacks the history of Jinja, located $80 \mathrm{~km}$ east of Kampala, seeking to understand how industrial developments during the early 20th century contributed to its growth. To understand the historical complexities of the built environment, the paper seeks clarity on decisions that led to Jinja's spatial developments alongside economic, social and political context of colonial 
patronage. Studying these past events should provide a clear understanding of Jinja. We can discern different notions and theories of city growth and development in the development of these urban centres, more so the relationships that existed between Britain and its colonies. The genesis of this relationship is explored in the Section 2 of this paper which also explores colonial developmental patterns that contributed to the development of these urban centres. Industrial developments did not solely contribute to growth of urban centres, trade impacted urban growth at a socio-economic level investigated in Section 3. Jinja's foundations of growth, the main focus of Section 4, addresses Jinja's industrial roots with a backdrop of colonial developments and Jinja's relationship to urban centres within British East Africa. The planning of colonial urban space had correlated general trends between Britain and sub-Saharan Africa and so Section 5 discusses the planning principles applied. Section 6 then connects colonial developments, trade, planning with industry and Jinja's urban and built form.

\section{EMBRYONIC URBAN CENTRES UNDER THE AUSPICES OF COLONIAL DEVELOPMENTS}

At the beginning of the 20th century, urban centres within British controlled territories across sub-Saharan Africa were inclined towards industrial activities, which were influential in their growth and development. The first pattern was associated with transport systems which became anchors of trade along which embryonic urban centres emerged [4]. The second pattern focused on the exploitation of agricultural produce such as cotton, cocoa, tobacco and coffee. Cash crop agriculture became concomitant with trade, commerce and transport systems within colonies, epitomised by railways that linked territories which had such raw materials with coastal ports [5]. The third category of patterns was political and administrative in its entirety, which had the greatest impact on the emerging urban space since colonial developmental policies pervaded sectors of the political and economic structure. The new industrial urban centres were located away from existing political or commercial centres and established trade routes [6], because the existing urban centres were oriented towards indigenous complex economic activities with massive amounts of commerce and craft activities [7]. Since colonies were geographical extensions of the metropolitan state and subordinate to it [8]; urban centres within colonies became nuclei for colonial administration and urban development [9]. They received and distributed produce from the countryside to the region(s) beyond the colonies and vice versa.

The Uganda Railway linked the East African coast with the fertile Lake Victoria basin in 1901 and on its way, it opened up the fertile highlands of British East Africa (now Kenya) to commercial agricultural exploitation. Notable in this regard, is Nairobi founded in 1899 as a railway service point along the Uganda Railway line and Port Florence (now Kisumu) which was the Uganda Railway's terminus on Lake Victoria. Nairobi and Port Florence were resolute representatives of urban centres that became the administrative strongholds for the colonial government (Fig. 1). These centres were defined by: railway administration which managed infrastructure related to the railway, and included the marshalling yard, station, staff housing; and colonial (provincial) government administration that presided over government offices, bazaar, residential areas and the rest of the urban area. This setup represented colonial developments infused in institutional frameworks of budding colonial urban centres across sub-Saharan Africa at the beginning of the 20th century.

Industrial developments' contribution to founding of urban centres can therefore be restated as when the Uganda Railway introduced nodes as railway stations and termini that eventually became administrative and commercial centres for the British colonial 


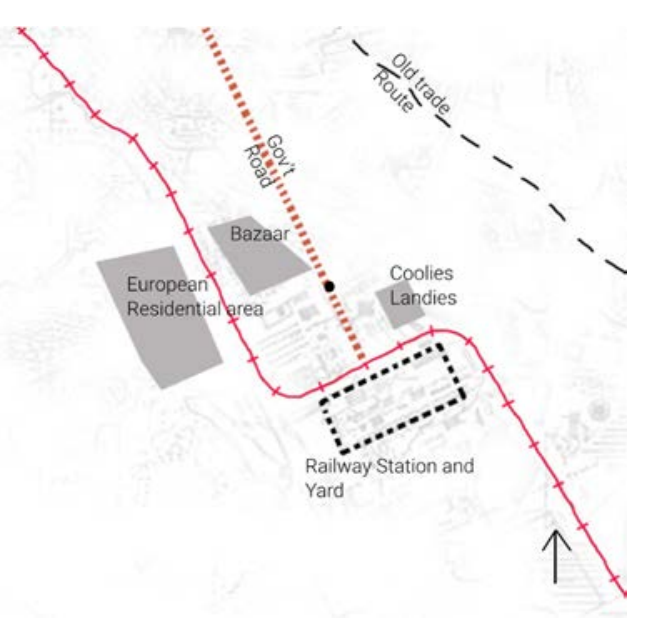

(a)

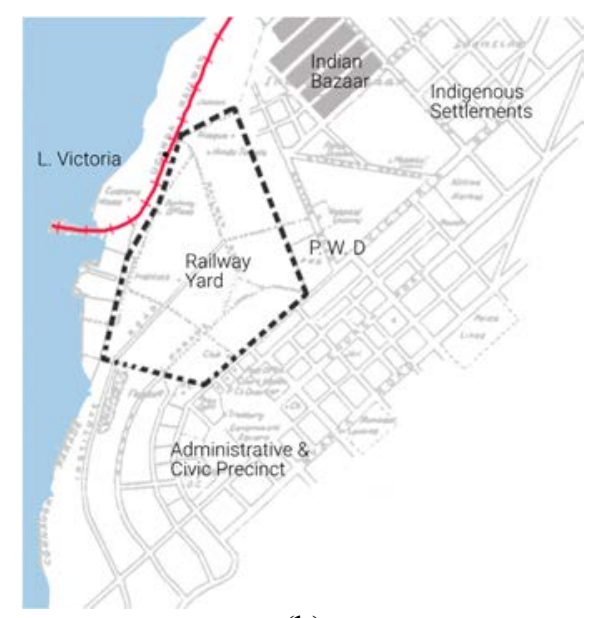

(b)

Figure 1: Colonial urban centres. (a) Nairobi in 1903; and (b) Kisumu in 1905. (Source: (a) Author; and (b) [14].)

government. Further, these urban centres presented cases that were rooted within colonial developments: the Uganda Railway construction for example brought with it a vast skilled workforce from India with $20 \%$ staying on as traders or artisans [10]. By the start of World War I, the colonial government encouraged migration and settlement of Indians in British East Africa with the anticipation that Indians would be used for military service [11], or that Indians would take on cotton and coffee farming [11], [12]. Instead majority of the Indians took up trade and craftsmanship [13].

\section{IMPACT OF TRADE ON URBAN GROWTH}

Trade and its inevitable affiliation with transport enticed people away from their traditional livelihoods [15], playing a pivotal role in the expansion of urban life. The shift in transport from human porterage to road and railway transport [16], [17] shortened the time needed to carry bulk commodities between Uganda and the East African coast [18] and in turn aided growth of colonial urban centres that were linked to this transport system. The growing Indian population took on trade and commercial activities after the Uganda Railway was completed, emerging as shopkeepers (dukawallah) [11]. Indian "dukawallah" began business dealings with larger established white merchants some of whom were British-based companies. Indian "dukawallah" became characteristic features of colonial urban centres across British East Africa and Uganda Protectorate [12], partly because the colonial government enforced compulsory town dwelling for Indians [13]. An outcome that was attributed to Indians as the middleman population between British and indigenous populations and they acted as the main outlet for produce from rural communities. Business entrepreneurs who became prominent across trading territories of British East Africa and the Uganda Protectorate included: Allidina Vishram, Nanjibhai Mehta and Muljibhai Madhvani. They supplied goods to "dukawallahs" along the Uganda Railway line [11] and in turn contributed to the vitality of colonial urban centres. The Indian trade and commerce influence over colonial urban space continued to expand throughout World War I, with the processing sector of the Uganda Protectorate eventually dominated by "Indian capital". Colonial urban centres thus supplanted the social functions of caravan camps, attracted local retailers and transregional 
merchants [19]. They articulated the flow of capital, people, commodities and cultures and as they expanded, became major trade instruments of British Empire throughout the colonial era [20].

\section{JINJA'S INDUSTRIAL ORIGINS}

Jinja grew to become the industrial "hub" of the Uganda Protectorate about 50 years after Winston Churchill [21] predicted that

"Jinja is destined to become a very important place in the future of Central Africa [...] In the years to come the shores of this splendid bay may be crowned with long rows of comfortable tropical villas and imposing offices and the gorge of the Nile crowded with factories and warehouses" [21].

The transformation of Jinja was a gradual process that involved a series of changes in Jinja; from a fishing village, to an administrative and commercial centre, and transport hub within Eastern Uganda. During the first three decades of the 20th century, the earliest industrial aspects of Jinja can be traced at the time when the Uganda Railway reached Kisumu in 1901 and when the Busoga Railway was completed in 1912 (Fig. 2). The Busoga Railway, was built to serve the region north of Jinja which was endowed with cash crop agriculture [22]. Cash crop agriculture was initiated by the colonial government, which encouraged both Indians and indigenes to grow cotton and coffee, the main commodities that was transported to Jinja along the Busoga Railway [23]. Jinja occupied a strategic lakeside position on the transport route to British East Africa via the railhead at Port Florence and had functional importance as a node within the East African network of trade and commerce. As industrial developments opened up Jinja's opportunities, political and economic factors played a pivotal role in the next burgeoning stage. The urban centre became the principal trading centre within the eastern region of Uganda where a number of larger Indian (and to a much lesser extent also European) trading firms had located their headquarters. Alongside a fishing village, headquarters for the Eastern Province of the Uganda Protectorate was established at Jinja in 1906 which made the place an administration for the physical and socio-economic spatial (re)ordering. Just as the political and economic developments in British East Africa shaped the spatial patterns of Nairobi and Kisumu at the beginning of the 20th century, the urban growth of Jinja was in turn influenced by correlated colonial developmental paradigms. Upon this foundation, lies the earliest impact of industrial development on Jinja's growth before it was designated the pre-eminent industrial hub of Uganda.

\section{PLANNING CONSIDERATIONS OF COLONIAL URBAN SPACE}

Planning of urban centres in colonial Africa borrowed principles from the trending early 20th century planning ideologies of the Garden City movement in England (Fig. 3), and segregation doctrines of hygiene. The doctrines were suggested by W.J. Simpson; a medical doctor from the London School of Hygiene and Tropical Medicine, and F. Lugard; a colonial administrator from 1901 to 1928 in British colonial Africa [3]. Planning from a medical perspective, interlaced with racial prejudice, political convenience and economic advantages had a dominant influence in shaping colonial urban centres [24]. For example, the immediate surrounding area of Nairobi's railway station became crowded, unhygienic and unhealthy for residential purposes [25], and so health related policies dictated that the British population be located away from the station. Garden City principles were visible in the planning of colonial Lusaka in the 1930s, a railway town in Northern Rhodesia (Zambia), grounded on 


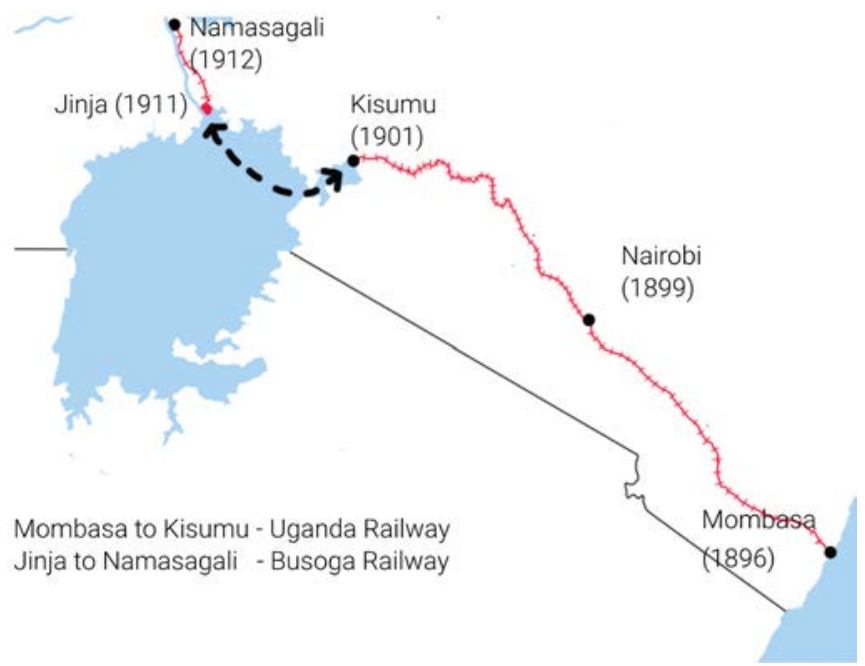

Figure 2: Early 20th century railways in East Africa. (Source: Author.)

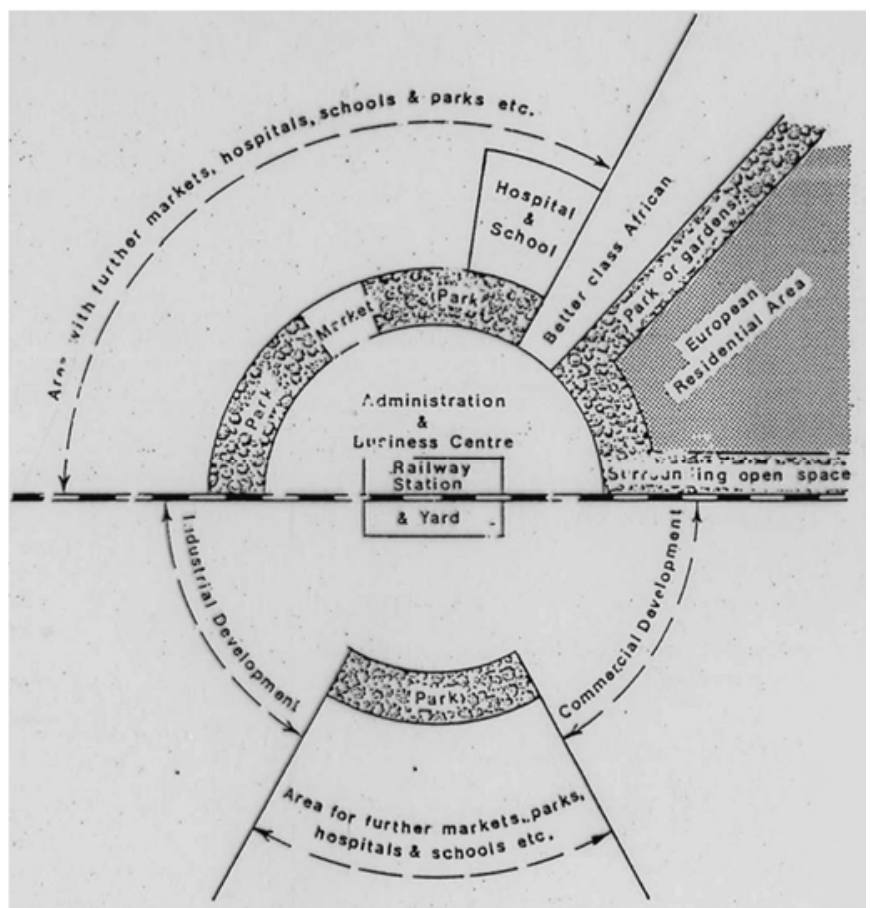

Figure 3: General physical planning approach to new railway towns in Africa [3].

spacious garden city concepts, with strict controls on the migration of Africans from rural areas [26]. Africans whose labour was needed were permitted into the urban area which contradicted the garden city concept of social inclusion [27]. Therefore, part of the Garden 
City concepts were applied to colonial urban centres such as; codification of the density of plot sub-divisions and standards of housing construction [28]. Planning became an avenue within the colonial ideology whereby a dominance-dependence relationship between the coloniser and colonised was manifested [29]. Hence planning concepts of urban space created an administrative management system that had evidence of control of inferior races [3], [30].

\section{INDUSTRIAL INFLUENCE ON JINJA'S URBAN AND BUILT FORM}

The urban form of Jinja consisted of physical patterns and layouts within the Indian bazaar areas and British quarters, which determined the shape, size and density of plot sizes within the urban zone. This urban form and layout was influenced by factors that included the industrial emergence of the Busoga Railway line and the triple heritage interaction based on archetypes of British, Indian and Indigenous influences - a concept formulated by Mazrui [30] to explain the historical and political development of Africa. The industrial influence on the urban layout of Jinja is apparent on a map in Fig. 4 that shows the Nile Crescent road parallel to the Busoga Railway line and how it defined the eastern boundary of Jinja's urban area during the early 20 th century.

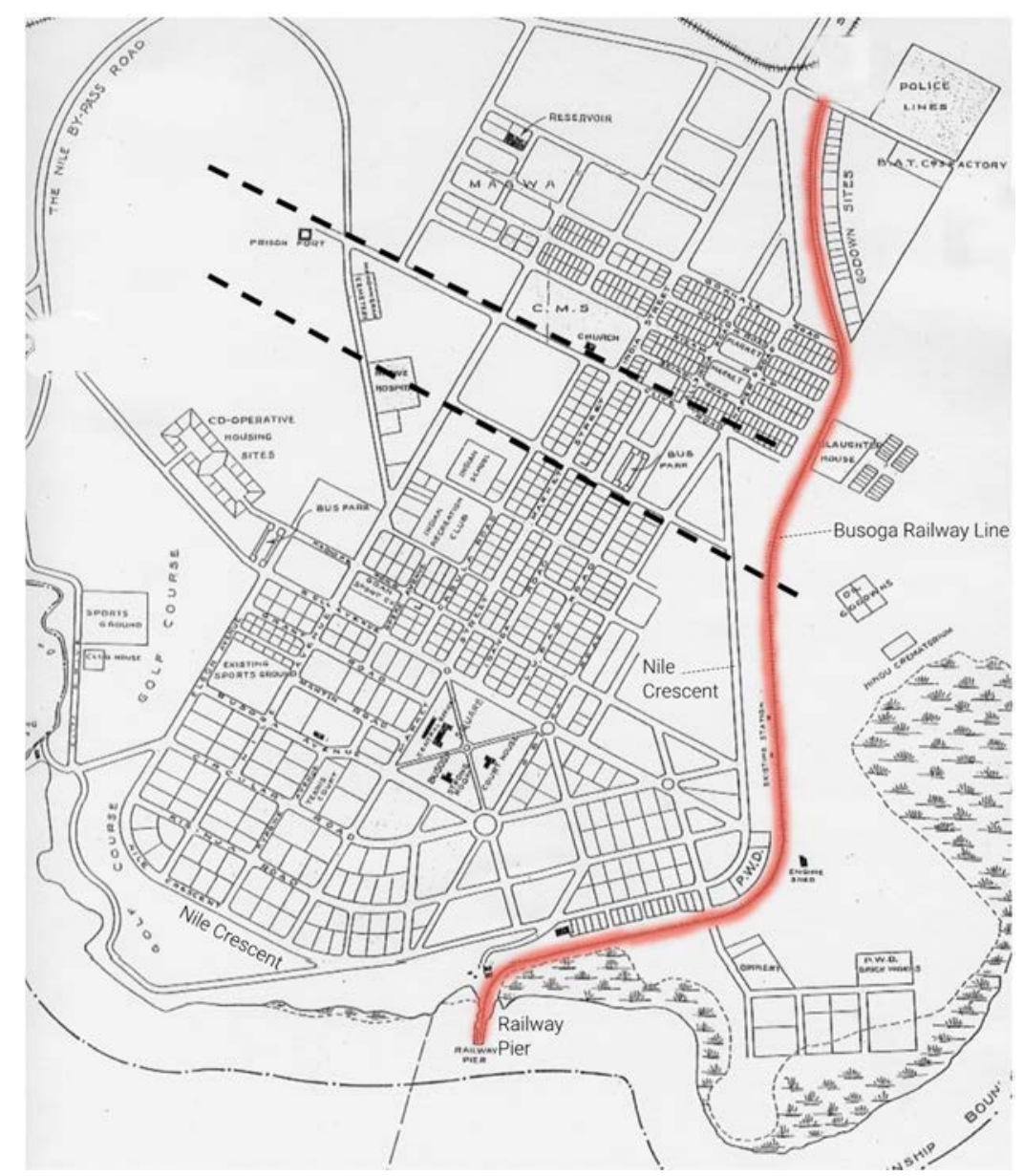

Figure 4: Jinja 1930 [32]. 
In order to understand the urban form of Jinja at the start of the 20th century, the words of Mumford [31] offer unwavering clarity that "[...] one must take one's eyes off the buildings, then, and look more closely at the citizen" [31]. The "citizens" of Jinja were of three categories; the British, the Indians and the indigenes, influencing the urban form at different scales. The British, with the administrative responsibility planned Jinja's layout and instilled colonial development policies. Within the British residential zone (Fig. 5) were government buildings, collectorate buildings, a post office and British residences for administrators and commissioners. This British zone was located uphill from the railway pier and dock for administrative and surveillance purposes. Myers [29] makes note of this as a spatial strategy of objectifying space through providing points of observation in a study that thematically "enframed" and "reframed" African "colonial" urban centres.

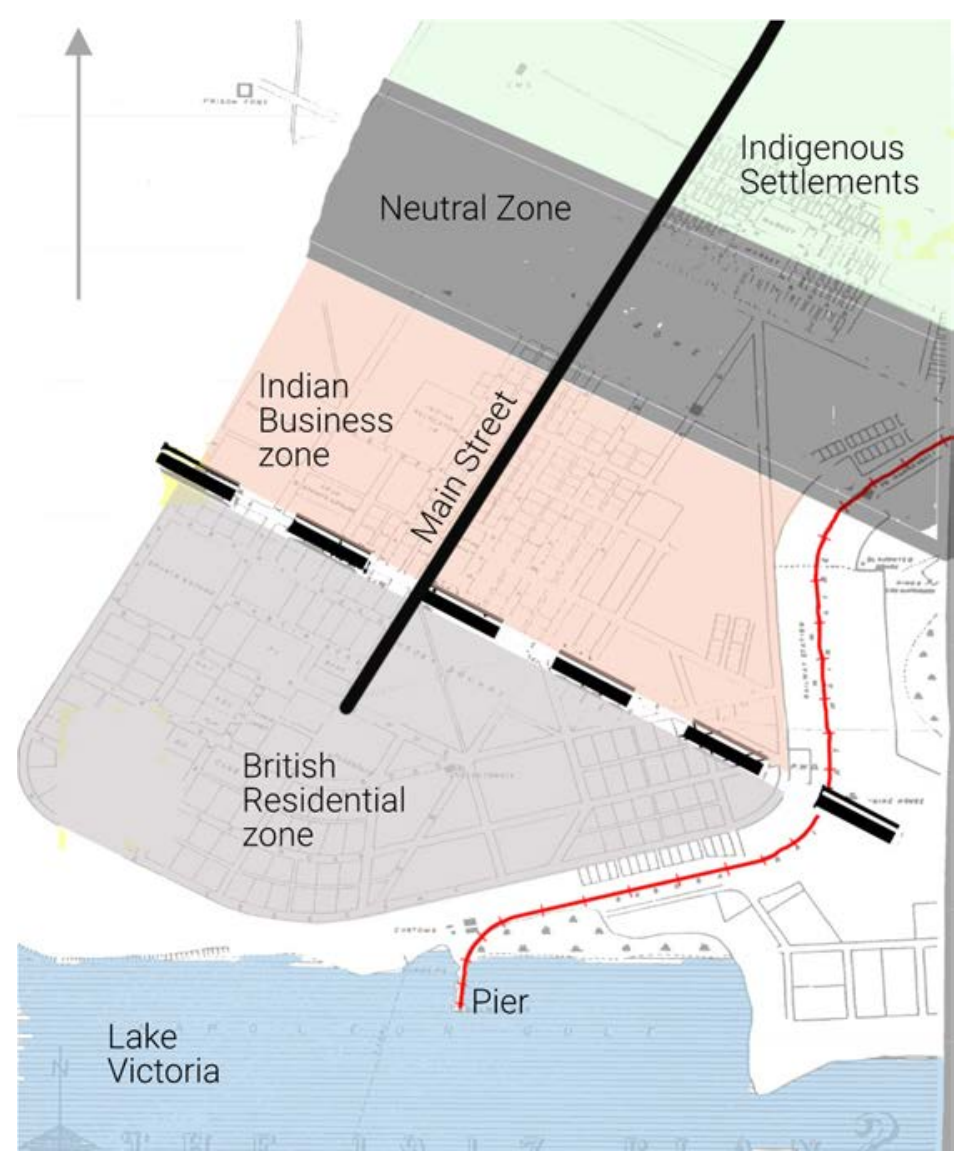

Figure 5: Jinja's urban zones 1917 [33].

Indian and indigenous urban residents were housed north of Boundary Road-Nile Avenue (dashed line in Fig. 5). Key spatial developments located in this area entailed: a native hospital, clerk's quarters, Indian residences and a market. The eventual urban zones were influenced by colonial planning ideologies that pervaded urban space, complemented by racial hierarchy. When racial tensions simmered from about 1906 to 1914, Main Street was 
the only built up street that traversed the neutral zone (Fig. 5). Stretching about $1.8 \mathrm{~km}$, Main Street's trade activities had substantial contribution not only to the early 20 th century Indian patrons that played a significant role in building its image but also to the evolution of Jinja within socio-economic context.

Another influence on Jinja's urban form can be deduced from Lynch's [34] hypothesis that uncovering the motives behind any settlement gives clues to the connections between form values, environmental form and urban history. Jinja's founding was partly rooted in its becoming a relay point in the extraction of cotton and coffee from Busoga region. A functioning society, based on Indian dominated trade, had developed within the first three decades of the 20th century and was linked to a particular built form that housed "dukawallah" traders, a building typology that has come to dominate the urban landscape of Uganda over the years.

The historic-industrial influence on the urban form can be inferred from; how and when various build typologies came into existence [35]. In the first category, typologies that had similar functions of housing businesses of the Indian "dukawallah" along Main Street during the 1930s. These buildings are shown in Fig. 6 and are currently used as retail spaces.

In the other category, the building's functions changed over time while maintaining the urban form. Two examples stand out in this category; The Madhvani building (Fig. 7) and the Source Café building (Fig. 8) on Main Street.

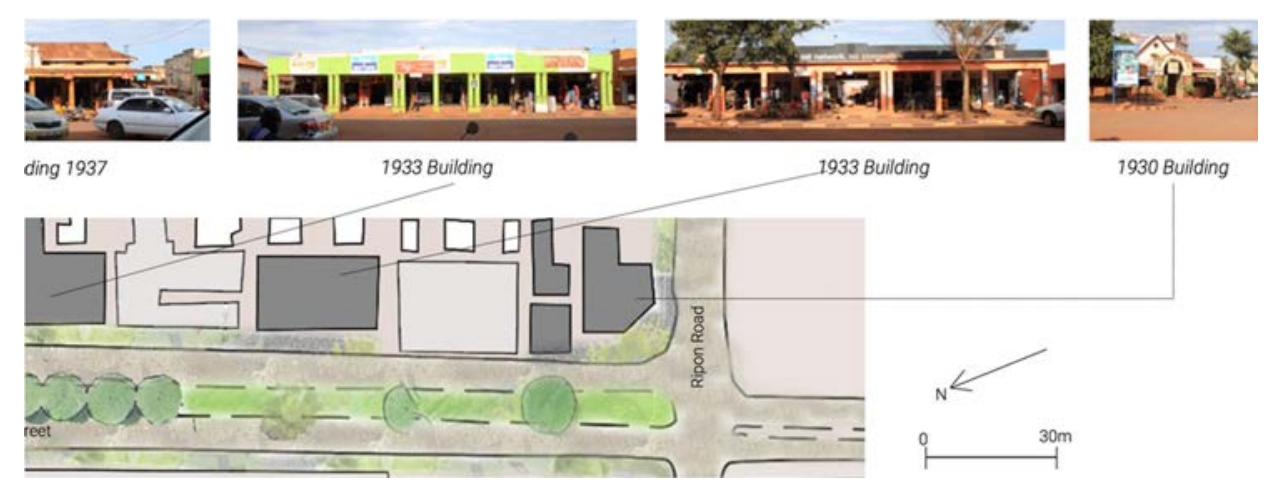

Figure 6: Part of Main Street, Jinja. (Source: Author.)

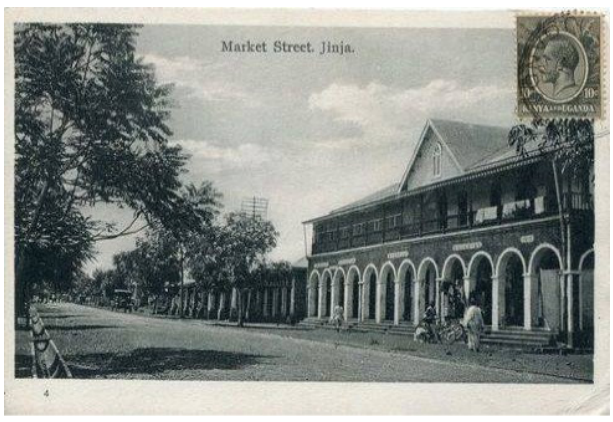

(a)

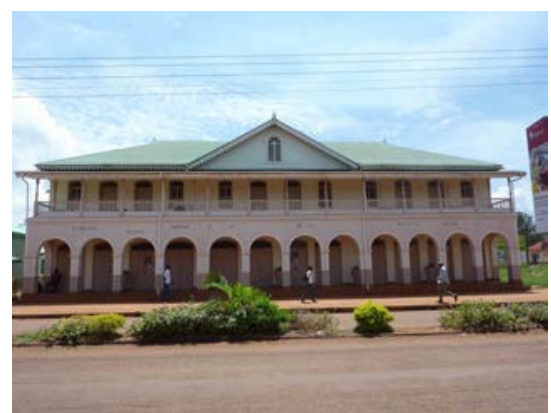

(b)

Figure 7: Madhvani building. (a) In the 1920s; and (b) In 2016. (Source: (a) [36]; and (b) Author.) 


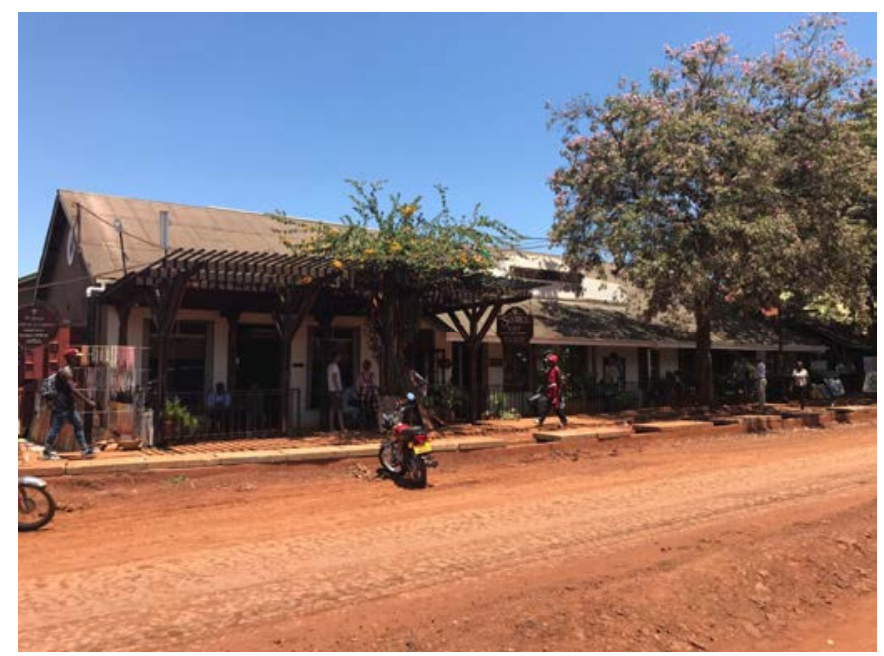

Figure 8: The Source Café building 2018. (Source: Jim Joel Nyakana.)

The Madhvani building was completed in 1919 and became the head office for Vithaldas Haridas and Company in addition to apartments on the upper level. It later became offices for Muljibhai Madhvani and Company and in 1947 was the headquarters for two sugar factories, eighteen cotton ginneries and a tobacco company. This building attains its significance as the cornerstone of the Madhvani business empire - one of the largest privatesector investor of industry in Uganda today. The latter (Fig. 8) was completed in 1924 and housed a bakery, under Indian ownership, then later became a kiosk and bar. This building currently houses a restaurant, library, craft store, as well as a prayer space.

\section{REFLECTIONS, HERITAGE VALUE AND CONCLUSION(S)}

To understand the built form of Jinja is to go beyond mere description, to analyse the sociopolitical and socio-economic processes by which such built form(s) came into existence. The current built form of Jinja includes buildings that belong to different periods: the early 20th century, art deco periods of the 1930s, modern period of 1940 s to $1960 \mathrm{~s}$, late 20th century and the recent period from the start of the 21 st century. Two periods: the early 20 th century and Art Deco period of the 1930s coincided with the emergence of railways and their associated developments in Jinja and the wider British Empire across sub-Saharan Africa. This period marked the beginning of Indian industrial patronage and influence on the urban development of Jinja. The significance of a collection of historic buildings within Jinja's urban area can therefore be partly accredited to Indian communities who were involved in their establishment. The magnitude of Indian economic dominance is of outstanding merit to the birth of Uganda's economy and is worth emphasising. Historic buildings along Main Street and its environs remain as physical evidence of the rise of Indian business enterprise in Jinja. When Jinja was designated the pre-eminent industrial hub of Uganda, Main street continued its predominance by housing retail outlets and offices for booming industries.

With regards to indigenous settlements, there is virtually no information about the built forms of the fishing village that existed in Jinja before 1900. The urban centre, before commencing the construction of the Busoga Railway in 1911 is reported by Sofer and Sofer [18] to have had a relatively low number of 396 indigenes compared with an Indian 
population of 531. With the majority Indian population and their trade knowledge, Indian influence became more visible in the built form. The indigenous population on the other hand supplied labour to both European and Indian urbanites in their residences, colonial administrative offices and the Indian dukawallah. Integral to this labour supply, was the African housing estates for railway employees and the Walukuba African housing estates to house thousands of workers and civil servants that would be required for labour during the Owen Falls Dam project.

As a synopsis of the contribution of industrial activities towards the growth of urban centres across sub-Saharan Africa, this paper provided a worthwhile framework from which it is feasible to evaluate the industrial developments that aided the growth of Jinja. This paper presented an outline of colonial developments under the guise of transport and the impact of trade on urban growth seeking to frame the study in its socio-economic and socio-political context of colonial patronage. Investigating how these aspects of colonial developments played a key role in the growth of colonial urban centres, is therefore of concern and forms a basis for conservation policies of urban heritage within Jinja.

\section{ACKNOWLEDGEMENTS}

I would like to thank Dr Mark R.O. Olweny for guiding and advising me through this complex, often overwhelming experience. Your knowledge, expertise and patience have been invaluable and I am grateful to have been able to work with you. To my peers, Joseph Kasimbi and Gilbert Kafuma, thank you for the constant review and critique sessions and seminars. Finally, I would like to thank the Cross-Cultural Foundation of Uganda (CCFU) supported by European Union for inviting me to participate in the documentation of historic buildings in Jinja, Kampala and Entebbe. This exercise was deeply rewarding and extensively contributed to the buildup of this paper.

\section{REFERENCES}

[1] Memon, A., The Spatial Dynamics of Trade and Urban Development in Kenya during the Early Colonial Period up to 1915, p. 78. Nairobi, 1973.

[2] King, A. \& Van Zwanenburg, A., An Economic History of Kenya and Uganda, 18001970, MacMillan Press: London, pp. 123-145, 1975.

[3] Home, R. \& King, A., Urbanism and master planning: configuring the colonial city. Architecture and Urbanism in the British Empire, ed. G. Bremner, Oxford University Press: Oxford, pp. 51-85, 2016.

[4] Davidson, B., Modern Africa: A Social and Political History, Pearson Education: London, 1994.

[5] Taiwo, O., How Colonialism Preemptied Modernity in Africa, Indiana University Press: Bloomington, pp. 128-157, 2010.

[6] Spear, T., A town of two strangers or model modern east African town: Arusha and the Arusha? Africa's Urban Past, eds D. Anderson, \& R. Rathbone, James Currey Publishers: Oxford, pp. 109-132, 2000.

[7] Freund, B., The African City: A History, Cambridge University Press: New York, pp. 37-106, 2007.

[8] Mamdani, M., Politics and Class Formation in Uganda, Fountain Publishers: Kampala, pp. 40-120, 1999.

[9] Boahen, A., Colonialism in Africa: Its impact and significance. UNESCO General History of Africa Volume VII: Africa Under Colonial Domination 1880-1935, ed. A. Boahen, Heinemann Educational Books: London, pp. 782-810, 1985. 
[10] Green, N., Africa in Indian ink: Urdu articulations of Indian settlement in East Africa. Journal of African History, 53(1), pp. 131-150, 2012.

[11] Metcalf, T., Imperial Connections: India in the Indian Ocean Arena, 1860-1920, University of California Press: Berkeley, pp. 165-204, 2007.

[12] Ghai, D.P. \& Ghai, Y.P., Asians in East Africa: Problems and prospects. The Journal of Modern African Studies, 3(1), pp. 35-51, 1965.

[13] Morris, S., Indians in East Africa : A study in a plural society. The British Journal of Sociology, 7(3), pp. 194-211, 1956.

[14] Anyumba, G., Kisumu Town: History of Built Form, Planning and Environment: 1890-1990, Delft University Press: Delft, pp. 75-110, 1995.

[15] Roberts, A.D. (ed.), The Imperial mind. The Colonial Moment in Africa: Essays on the Movement of Minds and Materials 1900-1940, Cambridge University Press: Cambridge, pp. 24-77, 1986.

[16] Caldwell, J., The social repercussions of colonial rule: Demographic aspects. UNESCO General History of Africa Volume VII: Africa Under Colonial Domination 1880-1935, ed. A. Boahen, Heinemann Educational Books: London, pp. 458-487, 1985.

[17] Wrigley, C., Aspects of economic history. The Colonial Moment in Africa: Essays on the Movement of Minds and Materials 1900-1940, ed. A.D. Roberts, Cambridge University Press: New York, pp. 77-140, 1986.

[18] Sofer, C. \& Sofer, D., Jinja Transformed: A Social Survey of Multi-Racial Township, East African Studies: Kampala, pp. 4-16, 1955.

[19] Reichart-Burikukiye, C., The railway in colonial East Africa: Colonial iconography and appropriation of a new technology. Landscape, Environment and Technology in Colonial and Postcolonial Africa, eds T. Falola \& E. Brownell, Routledge: New York, pp. 62-87, 2012.

[20] Beall, J. \& Fox, S. (eds), Cities and Development, Routledge: London, pp. 34-67, 2009.

[21] Churchill, W., My African Journey, Richard Clay and Sons: Toronto, pp. 1-180, 1909.

[22] O'Connor, A., New railway construction and the pattern of economic development in East Africa. Transactions of the Institute of British Georgraphers, 1(36), pp. 21-30, 1965.

[23] Nayenga, P., Commercial cotton growing in Busoga District, Uganda, 1905-1923. African Economic History, 10, pp. 175-195, 1981.

[24] Curtin, P., Medical knowledge and urban planning in colonial tropical Africa. The Social Basis of Health and Healing in Africa, eds S. Feierman \& J. Janzen, University of California Press: Berkeley, pp. 235-256, 1992.

[25] Njoh, A., Colonial philosphies, urban space, racial segregation in British and French colonial Africa. Journal of Black Studies, 38(4), pp. 579-599, 2008.

[26] Chitengi, H., Deriving Lessons for Urban Planning and Housing from the Resilience of Informal Housing Systems in Zambia, University of Dundee: Dundee, 2015.

[27] Bigon, L., Garden cities in colonial Africa: A note on historiography. Planning Perspectives, 28(3), pp. 477-485, 2013.

[28] Panerai, P., Castex, J., Depaule, J. \& Samuels, I., Urban Forms: The Death and Life of the Urban Block, Architectural Press: Oxford, pp. 30-56, 2004.

[29] Myers, G.A., Verandahs of Power: Colonialism and Space in Urban Africa, Syracuse University Press: New York, pp. 33-75, 2003. 
78 Structural Studies, Repairs and Maintenance of Heritage Architecture XVI

[30] Mazrui, A., Ali Mazrui and the triple heritage: A contextual essay. Debating the African Condition: Ali Mazrui and His Critics, eds A. Mazrui \& W. Mutunga, African World Press: Asmara, pp. 21-27, 2004.

[31] Mumford, L., The City in History: Its Origins, Its Transformations, and Its Prospects, Harcourt Brace Jovanovich: New York, 1961.

[32] Mirams, A.E., Jinja: Report on the Town Planning and Development of Jinja, Government Printer: Entebbe, 1930.

[33] Martin, C., Something About Jinja, Uganda, North West University Library: Illinois, 1956.

[34] Lynch, K., Good City Form, MIT Press: Cambridge, MA, pp. 5-37, 1981.

[35] Cuthbert, A., The Form of Cities: Political Economy and Urban Design, Blackwell: Oxford, pp. 23-51, 2006.

[36] Madhvani Group Magazine, 25(1), pp. 11-13, 2017. www.madhvanifoundation.com/sites/default/files/document/file/201704/madhvani_group_mag_vol_25_no.1_march_2017. 